\title{
Dual Specificity Protein Phosphatase 10
}

National Cancer Institute

\section{Source}

National Cancer Institute. Dual Specificity Protein Phosphatase 10. NCI Thesaurus. Code C129057.

Dual specificity protein phosphatase 10 (482 aa, $\sim 53 \mathrm{kDa}$ ) is encoded by the human DUSP10 gene. This protein plays a role in both the dephosphorylation and inactivation of MAP kinases. 